held from time to time in different towns throughout the country, its object being to form a bond of union among those who cultivate mineralogy or who wish to see this science restored to the place which it ought to hold in a land where so much scund geological work is being done. The Society publishes a "Mineralogical Magazine," of which three volumes and part of a fourth have already appeared. This publication contains numerous papers by Dr. Heddle and the indefatigable secretary, Mr. Collins, also some by Mr. Sorby, the late Mr. J. C. Ward, Prof. Bonney, and other well-known writers. No one need fear to encounter in its pages the resuscitated ghosts of the old mineralogical "Dryasdusts." Peace to their manes! They did good though limited work in their day, which deserves our respect for its thoroughness. But, with affectionate reverence for these early masters and their crabbed lingo, we breathe a more open breezy atmosphere now. The mineralogist's ken sweeps far beyond the limits of his cabinet and laboratory. Hand-in-hand with the geologist and palæontologist, being elder brother to both, he takes his share in the task of unravelling the structure and history of the earth. Towards the attainment of this union the Mineralogical Society aims, and it deserves the heartiest wishes for its success.

ARCH. GEIKIE

\section{SMOKELESS LONDON}

T WRITE for the purpose of expounding a scheme which, if adopted, would make London a smokeless city.

When taking upon myself to explain a subject in a few minutes which has taken many years to develop ir my own mind, there is a great temptation to put the reader in possession of the steps which led to the conclusion. The conclusion itself however has so much to recommend it that I will confine myself to the results of my reasoning only. It is enough to say that they were arrived at to a great extent by an exhaustive exclusion of less feasible plans.

First then I propose to take advantage of the existing plant of the gas companies. I find they are amply sufficient for the purpose.

Instead of taking I0,000 cubic feet of gas per ton from the coal, I propose to take 3333 cubic feet, and to pass three times the quantity through the retorts, or any other proportion that may be found most convenient. The result of doing so is startling.

The companies will have double the quantity of byproducts they have at present in the shape of tar and ammoniacal liquids; the community will have 24 -candle gas instead of 16 -candle gas; the fuel resulting from the process will light readily, and it will make a cheerful fire that gives out 20 per cent. more heat than common coal; London would become a smokeless city.

In dealing with the figures I shall take them roughly, but in such a way that by including a few outlying corporations they could be made absolutely correct.

I take the total annual consumption of coal in London to be $6,000,000$ tons. Of this I take $2,000,000$ tons to be the annual consumption of the gas companies. The total quantity of fuel used for general purposes I take to be $4,000,000$ tons of coal and $1,000,000$ tons of coke sold by the gas companies.

We shall now see what would be the result if we treat the whole of the 6,000,000 tons in the retorts on an extraction of less than three hours, instead of the six hours at present prevailing.

The total quantity of 16-candle gas consumed in London may be taken at $20,000,000,000$ cubic feet. This would be at the rate of 3333 cubic feet per ton upon 6,000,000 tons, the total quantity of coal consumed in London. The residual smokeless fuel would amount to 5, 100,000 tons. Of this $1,000,000$ tons would be required for the extraction of the gas, leaving 4,100,000 available for the general uses of the community. This has to be compared with the 4,000,000 tons of coal and the $1,000,000$ tons of coke already referred to as consumed at present. Now the smokeless fuel which results from an extraction of 3333 cubic feet of gas per ton has a heating capacity fully 20 per cent. greater than common coal, and ro per cent. greater than coke. This gives us the exact equivalents of the 5,000,000 tons of fuel at present in use.

So far the account as regards the fuel available for the community balances. We may now deal with the differ ence in value between I6 and 24-candle gas. As the value of the gas varies directly as its illuminating power, the calculation is very simple. If we take the average price of 16 -candle-gas to be $3 s .6 \mathrm{~d}$. per thousand cubic feet we shall find the total value of the $20,000,000,000$ consumed in London to be $3,500,000$ l, but as we have by my scheme the same quantity of 24 -candle-gas, the value will be increased to $5,250,000 l$. ; here then we have an annual sum of $1,750,000 l$. to place to the credit of the system.

Turning now to the by-products : seeing the gas companies by the new arrangements would subject three times the quantity of coal to the heat of their retorts during the period when the tar and ammoniacal liquors pass off most rapidly, I do not think I am wrong in estimating the yield at double its present amount. Taking this upon the tar and ammonia to yield $3 s .9 d$. per ton of coal, we find the total value of these by-products to be, at present, on the supposed consumption by the gas companies of 2,000,000 tons of coal per annum, 375,000l. This being doubled under my scheme, an additional sum of $375,000 \%$. must be placed to its credit.

But the basis upon which we have hitherto been arguing is that the gas companies under the proposed scheme are getting their coal for nothing. We have been supposing that the community become the purchasers of 6,000,000 tons of coal and hand it to the gas companies. At present London only pays for its general consumption on $4,000,000$ tons of coal and $1,000,000$ tons of coke. Let us now suppose that the companies pay the same sum annually that they do at present for their coals; if so, they would pay upon 2,000,000 tons, or an annual amount of $1,600,000 \%$., if their coals cost $16 s$. per ton. From this falls to be deducted the money they at present draw from their sales of coke, which, when taken at $6 s$. yer ton of coal carbonised under the existing system, still leaves a sum of $1,000,000 l$., which they could afford to pay per annum for the use of the $6,000,000$ tons of fuel as proposed in my siheme. We will now take the total payments of the community for their coal to be upon $6,000,000$ tons, for which we will further suppose they pay at the rate of $16 \mathrm{~s}$ per ton first cost. This would amount to $4,800,000 l$. per annum. From this falls to be dedacted the $1,000,000$ l. contributed by the gas com. panies for the use of the fuel, also the $1,750,000 l$. charged on the difference between the I6- and 24-candle gas already referred to, also the sum of $375,000 \%$. of additional income from the by-products. This would leave a net sum paid by the community for its fuel under my scheme of $1,675,000 l$. Under the present system they have to pay, say $16 s$. per ton on $4,000,000$ tons of coal, and say I2s. per ton on $1,000,000$ tons of colke. This makes in all the sum of $3,800,000$ per annum. Here then we have a balance in favour of my scheme of $2,125,000 /$. annually. This may be taken as the yearly value of London smoke, which I propose to convert into useful products by the plant at present in use.

I have only in conclusion to say one or two words about the efficiency of the scheme as regards the fuel. It lights easily, it gives off no smoke, it makes a cheerful fire, it gives out more heat than either coal or coke, it will be cheaper per heat-unit than the coal at present in use, London would become a smokeless city, and all that would fall to be deducted from the sum of $2,125,000 l$. per annum would be confined to a few items, such as the cost 
of addltional workmen employed in charging the retorts, interest upon additional capital required for transit appliances, and the terms to be made with the gas companies for carrying out the scheme. ${ }^{1}$

I cannot close without acknowledging the help I have received from $M r$. Wallace, the gas manager at Woolwich Arsenal, and the valuable information obtained from Mr. Field's tabulated accounts of the London gas companies. So far as I am aware my contributions to the Butilder and elsewhere are the only writing on the subject of my scheme that has ever been made public.

Westminster, December 13

\section{W. I. SCOTT MONCRIEFF}

\section{NEW GUINEA ${ }^{2}$}

O the few travellers who have attempted to explore the great island of New Guinea, Signor D'Albertis must undoubtedly be considered the chief, since he alone has made extensive and repeated journeys both in the north-western and the south-eastern parts of the island, and has thus been able to examine and compare some of the most distinct tribes or races which inhabit the country. The narrative of his travels has therefore been looked for with some interest, for though several of his journeys have been more or less fully described in newspapers and magazines, it was felt that much must remain to be told, and that so energetic a traveller would probably be able to throw some fuller light on the hitherto doubtful affinities and relations of the Papuan races.

Leaving Genoa in Norember, 1871, in company with the well-known traveller and botanist Dr. Beccari, and making short excursions in Java and the Moluccas, our travellers hired a small schooner at Amboyna in March, 1872 , to take them to Outanata, on the south coast of New Guinea ; and after some delays at Goram seeking a pilot and interpreter, on April $9 D^{\prime}$ Albertis records in his journal: "A memorable day! At last I tread the mys-

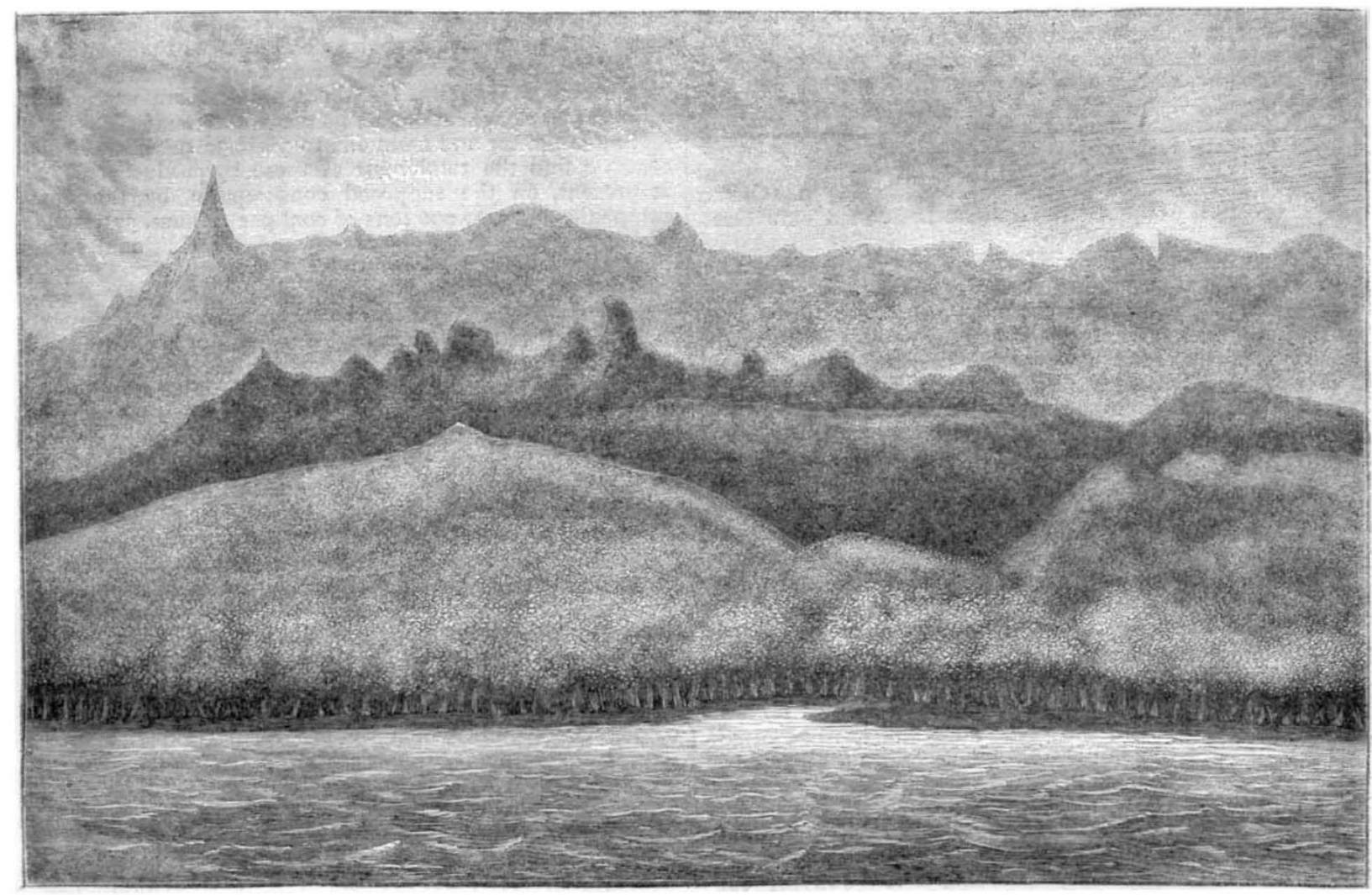

Fig. 1.-Mount Yule Range, seen from Yule Island.

terious land. At last, leaping on shore this morning, I exclaimed, 'We are in New Guinea!'"

Finding no safe or convenient place to stay at on the south coast, they proceeded to Salwati and fixed their abode for some time at Sorong, a small island close to the north-western extremity of the main land of Papua. From this point they made excursions into the interior, and D'Albertis resided some time at the inland village of Ramoi, where he was near dying of dropsy and fever. They then went in a native vessel to Dorey Harbour, where they arrived in August, and sttled themselves at Andai Village,

${ }^{I}$ By experiment I find that the grenter lacaing rower of the fuel in excesi of the coke more than makes up for the cocling which takes place on account of the more frequent charging of ihe retorts.

2 "New Guinea: What I Did and What I saw." By I. M. D'Albertis, Officer of the Order of the Crown of Italy, \&c., Sc. In two volumes. (London: Sampson Low, Marston, Searle and Rivingten, 188c.) where a German missionary resides. Here they had a house built, which was their headquarters till November, and D'Albertis succeeded in spending some weeks at Hatam, a village on Mount Arfak, about 3500 feet above the sea, and in the midst of the forests inhabited by the finest and rarest of the birds of paradise. On the very day after his arrival here he shot both the shielded and the six-shafted paradise-birds (Lophorina atra and Parotia sexpennis), two species which had certainly never before been seen alive or freshly killed by any European; and before he left this spot he obtained many other rare species, besides an altogether new and beautiful kind, which has been named Drepanomis albertisii.

Constant attacks of fever and dropsy, however, reduced him to such a state of weakness that it was absolutely necessary to scek a change of climate, and returning to 